\title{
The commodification of economic perspectives in Islamic Religious Education Studies on social media
}

\section{Heri Fathurahman}

Commercial Administration Study Department, Faculty of Administrative Sceinces, Universitas Indonesia

Email: heri.fathurahman@gmail.com

Umasih Umasih

History Education Department, Faculty of Social Sciences, Universitas Negeri Jakarta, Indonesia

Email:umasih@unj.ac.id

Gumgum Gumelar

Psychology Department, Faculty of Psychology, Universitas Negeri Jakarta, Indonesia

Email:ggumelar@unj.ac.id

Andy Hadiyanto

Islamic Education Department, Faculty of Social Sciences, Universitas Negeri Jakarta, Indonesia

Email: andy-hadiyanto@unj.ac.id

\footnotetext{
Assyifa Amelia Azzahra

Communication Department, Faculty of Social Sciences, Universitas Negeri Jakarta, Indonesia

Email: assyifaamelia_ikom18s1@mahasiswa.unj.ac.id
} 


\section{Abstract}

Economic empowerment in Indonesia is quite dynamically developing, this is also not free from the study of Islamic religious education on Islamic economics. Apart from this, researchers also used YouTube social media for review in this study. The formulation of the research problem is how to commodify an economic perspective in the study of Islamic religious education on social media. This study aims to analyze the commodification of economic perspectives in the study of Islamic religious education on social media. Researchers use a quantitative approach with a survey method where data will be taken from a predetermined population and sample and then a questionnaire to the respondent. The results of this study indicate that the commodification of YouTube content about the economy packaged in Islamic Religious Education affects the attitudes of YouTube users who watch the content. This is evidenced by conducting a regression test with the results that all ha received and accepted are declared good. In addition, economic empowerment in the perspective of Islamic religious education can also increase community economic empowerment and support the economic activities of the Indonesian people.

\section{Keywords: Economic Empowerment, Islamic Economics, New Media}

\section{INTRODUCTION}

Eddy, Usman, and Dafitri in their research stated that in the creative economy sector, there was an increase in GDP from year to year. In 2016, there was an increase of IDR 922 trillion, then in 2017 IDR 1,009 trillion, and IDR 1,105 trillion in 2018. This increase in GDP is considered to continue in the future. There are five types of sub-sectors that have contributed greatly to this increase in GDP, one of which is Film-Animation \& Video with a percentage of 10.09\% (Eddy, Usman, \& Dafitri, 2019). Creative video is one type of creative activity through recording or making moving images, which are then displayed on presentation media (Eddy et al., 2019)

Videos are more likely to be favored because of their more interactive nature because generally, video is a combination of audio and visuals. Through videos, there are lots of activities that can be done, such as learning math through YouTube. 


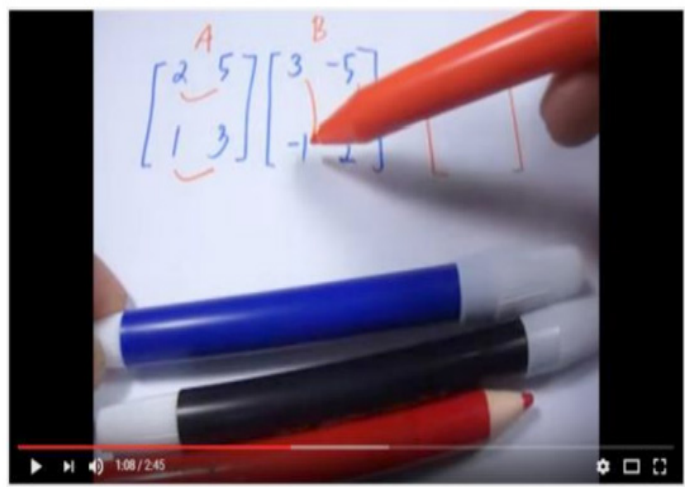

Cara Cepat Invers Matriks Matematika SMA

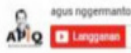

Figure 1. Example Learning Videos

Source: Youtube - Pembelajaran Matematika Lengkap dan Urut

The development of technology has led to the emergence of new platforms, one of which is Youtube. Youtube is a new media platform that is quite popular in Indonesia. Youtube allows everyone to act as a content creator and audience. This has made Youtube an attractive medium for the public (Ulya, 2019). Praditya in Ulya said that those who access the Youtube platform are considered capable of competing with those who view television as a medium of entertainment. It can be seen from the comparison of the presentation of Youtube users which is slightly proportional to television users, namely $53 \%$ for Youtube and 57\% for television (Ulya, 2019).

The freedom for someone to become a content creator on Youtube causes Youtube to have more diverse and complex content. Not only content that contains elements of entertainment, but also education. This educational content causes a lot of parties to currently using Youtube as a learning medium. One of them is in learning Islamic religious education. Research conducted by Baihaqi, Mufarroha, and Imani states that YouTube is a very effective supporting medium for learning Islamic religious education at SMK Nurul Yaqin Sampang (Baihaqi et al., 2020).

Of course, in Islamic religious education itself, various topics can be studied. The topic of economic activity is one of the most interesting discussions in studying Islamic religious education. The reason is none other than because the economy is an activity that is close to everyday life. For example, the 
explanation of saving in Islamic religious education, the law of usury in Islamic religious education, investment in Islamic religious education, and so on.

One of the content creators who packaged economic learning in Islamic religious education is MJS WTC Jakarta. On his Youtube channel, MJS WTC Jakarta discusses saving in Islam, then the law of usury in Islam, and much more. Apart from MJS WTC Jakarta, several other Youtube accounts also package economic learning through Islamic religious education, namely CNBC Indonesia, NGOBI, Tazkia TV, Bank Indonesia, and others.

Each Youtube user certainly has his assessment of the content posted on this platform. Included in economic learning content packaged in Islamic religious education. This subjective assessment causes a variety of attitudes that emerge from Youtube users. Therefore, this study aims to determine the attitudes of Youtube users towards the commodification of economic content packaged in Islamic religious education learning on Youtube. This research is expected to be useful for academics of Islamic Religious Education, especially in terms of using the Youtube platform as a learning support medium and packaging learning materials in broadcast Youtube content

Previous research conducted by Rahman (2015) on the credibility of YouTube as a medium for religious learning in contemporary Islamic civilization. This research explains that globalization in the development of the internet has opened up space for people to interact and get various information on border relief including religious edicts easily and efficiently through online media. The approach of proselytizing through the media online is parallel to the form of public acceptance which requires a new mechanism for the acceptance of religious edicts. YouTube is seen as a medium that may attract the $Y$ generation because of its nature that combines audio and visual elements in a method that is seen as more innovative and creative in the process of religious learning. YouTube is recognized as a video-sharing page for loading, watching, and sharing video clips. The credibility of the source of information is very important in ensuring that the information distributed meets the objectives and is accepted as a source that can be trusted. The basic source of Islam is the Koran and hadith. However, the overflow of announcements on the YouTube page has raised issues of the credibility of the notification content received by users. Qualitative methods, namely through literature review and review through reference materials are used in this study. The results of the investigation are expected to be useful and knowledgeable to the general public in making judgments about information in 
the media regarding online (Rahman \& Adam, 2015).

Previous research conducted by Baihaqi (2020) regarding the credibility of YouTube as a medium for religious learning in contemporary Islamic civilization. This research explains that youtube is a program, for tools, manipulation, and conveying information. The purpose of this study was to determine the impact of the application of Youtube as an effective learning medium for Islamic Religious Education. This study used a qualitative design with the location setting at SMK Nurul Yaqin Sampang. The technique of collecting data in this research is by making observations, interviews, and documentation. The analysis technique used is data reduction by comparing the results of interviews with other data. The results of this study are: (1) The learning process of Islamic Religious Education can make it easier to find information, manipulate, manage and transfer knowledge or transfer information; (2) Develop skills in the field of ICT for the smooth learning process; (3) Increasing teacher professionalism in the use of Youtube media, especially in Islamic Education lessons, and (4) Changing schools into creative and dynamic learning institutions so that students are motivated, always curious about Islamic Education learning. Effective learning requires good planning, one of which is the media that will be used in the learning process. The youtube application as learning support is a very effective medium in learning Islamic education in the technology era in general, and especially at SMK Nurul Yaqin Sampang (Baihaqi et al., 2020).

Previous research conducted by Suwarno (2017) on the potential of YouTube as a source of learning mathematics. This study explains that the development of technology and information that is increasingly advanced makes computer-based technology applicable in the world of education. The use of computer technology is used as a learning medium or learning resource. Many learning resources are circulating online in the form of e-learning. Most of the material in Elearning is in the form of the text so that it is difficult for students to understand mathematics because the mathematics material contains explanations of the steps in solving math problems. For this reason, learning resources in the form of videos are an alternative to replace text media. The learning videos that have been created can be uploaded on video-sharing sites such as Youtube. The purpose of this study was to see the potential of YouTube as a source of student mathematics learning. The study used a descriptive qualitative approach with the researcher as the main instrument. Researchers analyzed mathematics learning resources uploaded to several channels on Youtube and conducted interviews with mathematics teachers and high school 
students about the opinion of Youtube as a source of learning mathematics. The results show that there is a Youtube channel that provides learning resources for mathematics for students to learn which is good enough to be used as a source of student learning. Based on interviews with math teachers and students, YouTube can be a potential source of learning mathematics, but several positive and negative sides need to be considered (Suwarno, 2017).

Previous research conducted by Faiqah (2016) on YouTube as a means of communication for the Makassarvidgram community. This research shows that the use of YouTube as a means of communication for the Makassarvidgram Community is quite helpful. This study also found the characteristics of youtube based on the perceived use by its users, based on each user's needs. Responses from informants regarding the advantages and disadvantages of YouTube as a means of communication that are more inclined to its advantages, make YouTube very effective and efficient as a means of communication for this community (Faiqah et al., 2015).

Previous research conducted by Iqbal (2019) on the development of a YouTube channel video blog (vlog) with a stem approach as an alternative media for online learning. This study explains that the results of product validation, the percentage of results obtained by the media expert's assessment are $84 \%$, the material experts are $84 \%$, and the IT expert's assessment is $72 \%$. Student responses in small group trials obtained a percentage of $87 \%$ and in field trials $83 \%$. Based on these results, it can be concluded that the YouTube channel video blog with the STEM approach is feasible to be used as an alternative media for online learning for SMA / MA students (Irwandani et al., 2019).

Previous research conducted by Kamhar (2019) on the use of social media YouTube as a medium for learning Indonesian in higher education. This study explains that there is a need for teaching media discussion. The teaching media used must be close to the daily lives of students such as social media, especially YouTube. Learning and chatting casually with family often use social media. The era of globalization and social media technology from the life of modern society. The habit of using social media can indirectly make users access information and learn the information they access, so it is not surprising that currently language development and dissemination is going very fast. This digital era marks that now society has become a modern society. The social media used in this research is YouTube (Kamhar \& Lestari, 2019).

Previous research conducted by Pratiwi (2020) on higher-order thinking skills in the use of YouTube as a medium for learning Indonesian. This 
study shows that (1) the use of YouTube is effective as a medium for learning Indonesian. (2) YouTube as a stimulus helps formulate material on which to base questions in certain contexts. (3) YouTube makes it easy for students to do easy, medium, and difficult questions (Pratiwi \& Hapsari, 2020).

Previous research conducted by Utaminingrum (2014) on higher-order thinking skills in the use of YouTube as a medium for learning Indonesian. This research shows that YouTube plays a positive role in learning behavior of South Korean culture by Soulmate Community members as K-pop fans. YouTube results in prosocial cognitive, affective, and behavioral effects on Soulmate Community members (Utaminingrum, 2014).

Previous research conducted by Sari (2020) on efforts to improve the quality of education by using YouTube as a teaching medium during the Covid-19 pandemic. This research shows that the teacher as the most important source in delivering learning material must have a thousand minds to achieve a qualified teaching quality. It is undeniable that the health emergency or the Covid-19 pandemic has changed the learning strategies of both teachers and students a lot. All components in learning activities must be able to follow the development trend of learning demands. The teacher's ability to master technology seems to have a new challenge when students and teachers can no longer meet face to face. Teachers must also be able to satisfy students' parents as customers of educational services. Teachers must also be able to fulfill the target of teaching completely and get results in the form of direct feedback from their students. Teachers are no longer upset because the feedback can be seen immediately after students are confirmed to be listening through the agreed media. Youtube as an alternative solution for learning media tries to improve the quality of teacher teaching during the Covid-19 pandemic as an oasis in the desert (Sari, 2020).

\section{LITERATURE REVIEW}

Previous research conducted by Ashidiqi (2019) This study aims to analyze the animated content of the YouTube Free Quran Education channel for reference Islamic education material and as a learning medium in Islamic Religious Education (PAI) learning in schools. . This research uses qualitative methods with content analysis. All data was taken by taking eight videos on the YouTube channel of Free Quran Education at random, then continued with the identification, classification, and analysis of animated content. Overall 
the results of the study indicate that there is six Islamic religious education material content that can be used as material or reference in Islamic Religious Education learning for teachers in schools. The six materials are education on Koran, Islamic history, fiqh, aqidah, hadith, and morals (morals). In addition to being a reference for teachers, the YouTube Free Quran Education channel can also be used as a medium for teachers and as a support for independent learning for students at home, because all material can be accessed by students at any time. and wherever they are (Muna Nur Azizah Ashidiqi et al., 2019).

Previous research conducted by Quennerstedt (2013) on YouTube interactions between agonism, antagonism, and dialogue. This study aims to explore what students and teachers do in physical education practice in terms of "didactic disruption," through analyzing YouTube clips of 285 sports lessons from 27 different countries. Didactic irritation is an event that Rønholt describes as requiring "didactic, pedagogical reflection and discussion, which in turn can lead to alternative thinking and understanding of teaching and learning." Based on Barad's idea of performativity to challenge our habitual anthropocentric analytical view of viewing educational visual data, and using narrative constructs, we also aim to give meaning to participants' actions, relationships, and experiences in YouTube clips. To do this, we present the juxtaposition of teacher and student narratives in three "didactic distractions": (a) a story from a track, (b), a story from a game, and (c) a story from a bench. The story recounts moving events in data that offer insight into experiences embodied in sports training, making student and teacher actions understandable in sports training. , antagonism, and dialogue. This study aims to explore what students and teachers do in physical education practice in terms of "didactic disruption," through analyzing YouTube clips of 285 sports lessons from 27 different countries. Didactic irritation is an event that Rønholt describes as requiring "didactic, pedagogical reflection and discussion, which in turn can lead to alternative thinking and understanding of teaching and learning." Based on Barad's idea of performativity to challenge our habitual anthropocentric analytical view of viewing educational visual data, and using narrative constructs, we also aim to give meaning to participants' actions, relationships, and experiences in YouTube clips. To do this, we present the juxtaposition of teacher and student narratives in three "didactic distractions": (a) a story from a track, (b), a story from a game, and (c) a story from a bench. The story recounts moving events in the data offering insights into the experiences embodied in sports training, making the actions of students as well as teachers in sports 
training understandable (Quennerstedt et al., 2013).

Previous research conducted by Mosemghvdlishvili (2012) on framing and praising God on YouTube. This research explains that Islam is a hotly debated topic on YouTube, consisting of about half a million videos, tagged with this word. This study provides empirical material regarding three aspects of Islamic representation: (a) how Islam is framed in user-generated videos; (b) how it is visualized, and (c) what is the motivation of the YouTubers who made the video. The theoretical framework of this study is based on two pillars. The concept of valence framing is used to identify positive/negative representation patterns. The motivation to make a video blog about Islam is examined from the perspective of the Uses and Gratifications Theory. The data consisted of a content analysis of 120 videos and 15 in-depth interviews with content producers. Despite some particularly offensive videos about Islam, the overall tone of the coverage appears to be balanced. However, images and ideas that are not appropriate for broadcast in the mainstream media repeatedly appear on this site (Mosemghvdlishvili \& Jansz, 2013).

Previous research conducted by Garrett (2015) on mapping self-guided learners for video tutorials on YouTube. The research suggests that while YouTube has many educational videos, the way independent learners use these resources has not been fully explained. Search engine query analysis to get help with the use of Microsoft Excel shows that some users are looking for a specific feature or function but are using very general terms. Because the same video is returned in response to different search terms, it may represent a relationship between two searches and can be used to create relationship maps. As a result, YouTube videos can be used to create maps for a variety of topics, which novice users may find useful. Overall, content for informal learners should align with user search strategies (Garrett, 2016).

Previous research conducted by Welbourne (2015) on the science of communication on YouTube. This research explains that youtube has become one of the largest websites on the Internet. Among the many genres, professional and amateur science communicators compete for the audience's attention. This article provides the first overview of communication science on YouTube and discusses the content factors that influence the popularity of communication science videos on the site. Content analysis of 390 videos from 39 YouTube channels was carried out. While professionally generated content is superior in numbers, user-generated content is far more popular. Also, videos that have a consistent science communicator are more popular than videos without the 
usual communicator. This study is an important first step in understanding the factors of content, which are increasing the popularity of communication science channels and videos on YouTube (Welbourne \& Grant, 2016).

Previous research conducted by Payne (2011) on assessing the impact of the YouTube experiential learning project on the acquisition of viral marketing knowledge. This study aimed to evaluate the effectiveness of experiential learning social media projects integrated into postgraduate marketing classes. As part of a semester-long project, students are asked to work in teams and create spoof videos, which are posted on YouTube. Student success is partly determined by the number of views for a particular video. After reviewing the results obtained from the semistructured survey, the research indicated that the inclusion of project experiences into the core curriculum was associated with student motivation, engagement, team management, and communication skills. Furthermore, this integration promotes the learning of technical and theoretical knowledge related to consumer-generated advertising and virtual viral marketing. Results and implications are discussed (Payne et al., 2011)students were required to work within a team and create a spoof video, which was posted on YouTube. Students' success was partially determined by the number of views made of the particular video. After reviewing the results obtained by a semistructured survey, the research indicates that the inclusion of an experiential project into the core curriculum was associated with student motivation, engagement, team management, and communication skills. Furthermore, this integration promoted learning of technical and theoretical knowledge related to consumergenerated advertisements and virtual viral marketing. Results and implications are discussed. (C) The Author(s.

Previous research conducted by Amarasekara (2018) on exploring gender gaps in YouTube science communication. This research explains that youtube has become the second most popular web search engine (see Alexa. com) and the premier website for individuals and organizations to distribute video content freely. Popularity statistics show that content related to Science, Technology, Engineering, and Maths is very attractive to YouTube viewers, but an analysis of the 391 most popular science, engineering, and math-themed channels reveals a conspicuous absence of female communicators, with only hosts 32 of these channels present themselves as female. To help understand the possible causes of this gap, an analysis was conducted of the popularity indicators and audience sentiment of 450 videos from 90 channels related 
to Science, Technology, Engineering, and Mathematics. Channels hosted by women were found to garner more comments per view, and a significantly higher proportion of appearance, hostile, critical/negative, and sexist/sexual comments (Amarasekara \& Grant, 2019).

Previous research conducted by Madathil (2014) regarding health care information on YouTube. The study explains that YouTube is being used as a medium to promote unscientific therapies and drugs that have not been approved by the appropriate institutions and could potentially change patient beliefs about controversial topics such as vaccinations. This review recognizes the need to design interventions so that consumers can critically assimilate information posted on YouTube with more authoritative sources of information to make effective health care decisions (Madathil et al., 2015).

Previous research conducted by Smith (2019) on exploring the development of a musical identity for primary education using ukulele and youtube. The purpose of this study was to understand how learning to play the ukulele affects the identity of music in primary education majors. Eighteen participants (17 girls, 1 boy) from two universities created YouTube playlists and recorded solo ukulele performances for their YouTube channel. Perceptions of musical identity were collected through written reflection, videotaped class sessions, and focus group interviews. We found that students' early life experiences informed their early semester perceptions of musical identity (past self), while classroom experiences contributed to higher levels of musical competence and participation, and meaningful changes in musical identity (present and future self). front). Music teachers should consider how the ukulele and YouTube can be used to promote individual expression, accountability, and self-learning. We encourage music teacher educators to use music biographies and YouTube as tools for culturally responsive teaching while creating a safe space for the development of a musical identity for less experienced/confident musicians (Smith \& Secoy, 2019).

Previous research conducted by Lestari (2013) regarding the use of youtube as a medium for learning English. This study explains that the challenges of the world of education in meeting the needs of the internet generation are quite large. This is due to their different life experiences, especially their experiences in using technology. The internet itself opens up many possibilities for integrating technology in classroom learning. Youtube is a learning media that can be integrated into learning subjects that are considered difficult by 
students. The purpose of this research is to see the extent to which Youtube can be used as a learning medium in English courses. The results showed that videos on Youtube can be used as a learning medium (Lestari, 2013).

\section{METHODS}

This study uses a quantitative approach with data collection techniques using surveys. Research with the survey method is a study that uses a written questionnaire or formal interview in data collection. The research respondents were selected by sampling (Neuman, 2014, p. 49). In this study, the questionnaire was distributed to 273 respondents in several research areas, namely Makassar, Bali, and Padang. Furthermore, the research data were analyzed using IBM SPSS Statistics 16.0. Validity and reliability tests were carried out to determine that the research instrument used was an appropriate measuring tool. The validity test was performed using $\mathrm{KMO}$ and the reliability test was used using Alpha Cronbach. As a result, the research instrument used is valid and reliable and is the right measuring tool for this study. Then, the data were analyzed using a linear regression test. As a result, there is a positive and significant relationship between the variables. Because researchers need more in-depth data, researchers also collect data by conducting in-depth observations and interviews with several informants face-to-face.

\section{RESULTS AND DISCUSSION}

The descriptive data of this research discusses the influence of the commodification of Youtube content on the economy packaged in Islamic Religious Education on the attitudes of YouTube users who watch the content. The commodification of Youtube content regarding the economy packaged in Islamic Religious Education is explained through six dimensions, namely the dimension of creativity, the dimension of innovation, the dimension of talent, the dimension of ideas, the dimension of ideas, and the dimension of human resources.

The dimension of creativity describes the ability of content creators to package economic content in Islamic religious education in a new or different way than other content that is also published on Youtube. Through this dimension of creativity, the audience can gain new experiences, namely studying the economy which is packaged in learning Islamic religious education. 


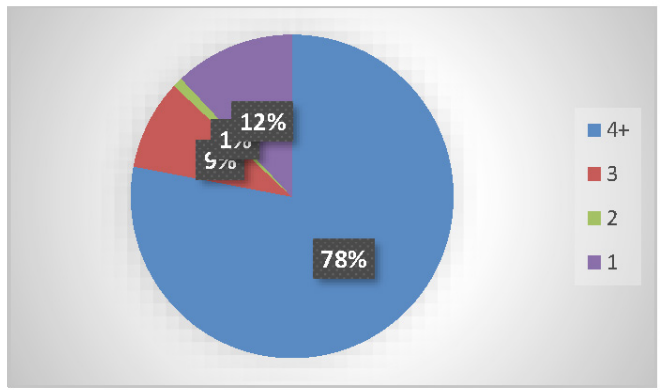

Figure 2. Results of Respondent's Answers on the Dimension of Creativity Source: Researcher Data

In Figure 2, it can be seen that $78 \%$ of respondents strongly agree that content creators have succeeded in making them gain new experiences in studying economics which is packaged in Islamic religious education learning, both in terms of visual, audio, and delivery of the content. However, as much as $1 \%$ of respondents answered disagree and $12 \%$ answered strongly disagree if content regarding economic learning which is packaged in Islamic religious education provides new experiences for them through content packaging, both in terms of visual, audio, and delivery of the material. The results of this study are consistent with research conducted by David et al. (2017) which states that content that is new and has interesting video quality is better than Youtube viewers and the attractiveness of the content itself (David et al., 2017).

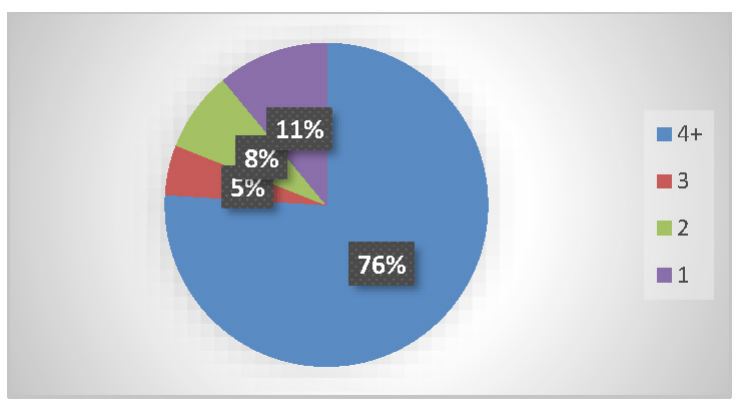

Figure 3. Results of Respondent's Answers on the Dimension of Innovation Source: Researcher Data

The innovation dimension describes the efforts of YouTube content creators to create something new in their content so that viewers are still interested in watching the YouTube content that is presented. For example, 
some Youtube channels create animated content. Then, several Youtube channels also present direct teachers or professionals who are experts in the field of economics but from an Islamic perspective. Based on the results of the respondents' answers, which can be seen in Figure 3, it is known that $76 \%$ of respondents strongly agree that innovation is needed in the presentation of content.

The innovations in question include the presentation of content using illustrations, presenting content using animated images, presenting content by presenting teachers who have credibility and are experts in their fields. Content creators can do a combination of these three things so that viewers don't get bored with the content presented. The results of this study are by the results of the analysis conducted by Rahmawan et al. (2018), which explains that Youtube content "Kok Bisa" which presents educational content is popular because the content is packaged with illustrations using animations and of short duration (Rahmawan et al., 2018).

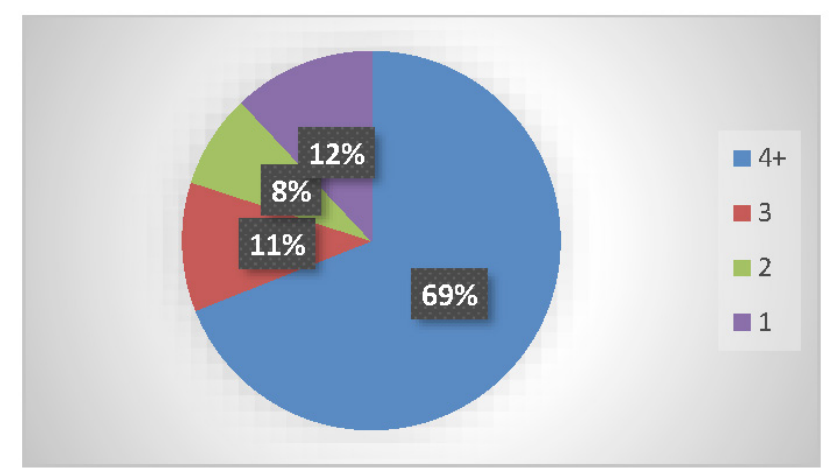

Figure 4. Results of Respondent's Answers on the Dimension of Talent Source: Researcher Data

The talent dimension describes the abilities and skills possessed by content creators in creating content about economics in Islamic religious education. In this dimension, content creators are required to be able to convey information communicatively to make it easier for the audience to understand the material presented.

Based on Figure 4, it can be seen that $69 \%$ of respondents answered strongly that talent is needed by content creators to make content more informative and interesting. The dimensions of talent can be in the form 
of abilities or skills possessed by content creators such as communicative, confidence, proficiency at something, outgoing, and so on. This is intended so that the audience does not feel bored and interested when watching the content. The results of this study are consistent with research conducted by Rahmawan et al. (2018), which explains that the "Quipper" Youtube channel is an interesting educational Youtube channel because it presents learning materials by presenting competent tutors in every field of knowledge or learning (Rahmawan et al., 2018). This means that someone's expertise in presenting content has a positive value in the attitude of the audience towards the content.

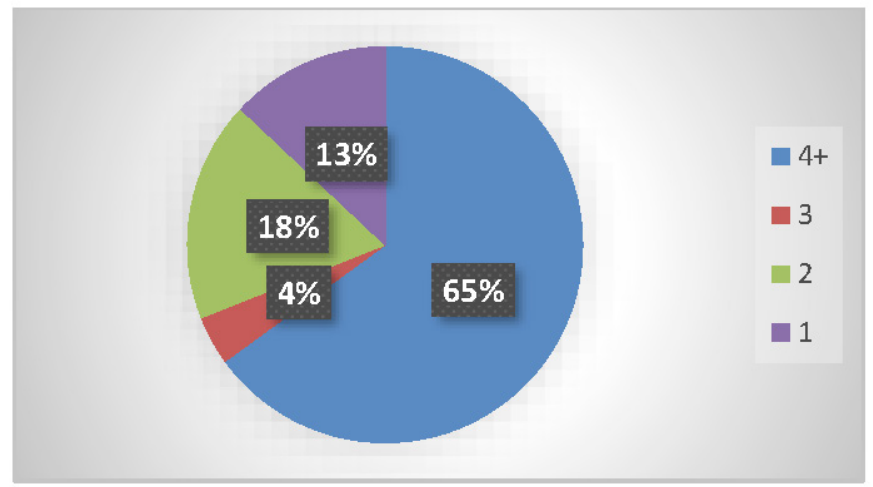

Figure 5. Results of Respondent's Answers on the Dimension of Idea Source: Researcher Data

The idea dimension describes the knowledge possessed by content creators in creating more innovative and creative content about economics in Islamic religious education. In this dimension, the audience can find out information about economics in Islamic education in different ways, such as by displaying animation or illustrations and accompanied by brief and clear explanations. This aims to make it easier for viewers to understand the content.

Based on Figure 5, it can be seen that $65 \%$ of respondents answered strongly agree that ideas are needed by content creators to create content about economics in Islamic education. In this case, ideas can be in the form of conveying someone's opinion or knowledge about economics in Islamic education which is packaged attractively so that the audience can easily understand the content presented. The results of this study are by research conducted by Ashidiqi, Rohmatiah, \& Rahmah (2019), which explains that learning Islamic Religious Education (PAI) can be done by analyzing animated content on YouTube's Free 
Quran Education channel as reference material. Islamic education in schools. All data was taken by taking eight videos contained on the YouTube channel of Free Quran Education at random, then continued with the identification, classification, and analysis of animated content. This means that ideas are needed by content creators so that the content presented can be interesting and become a reference for new learning material in Indonesia (Muna Nur Azizah Ashidiqi et al., 2019).

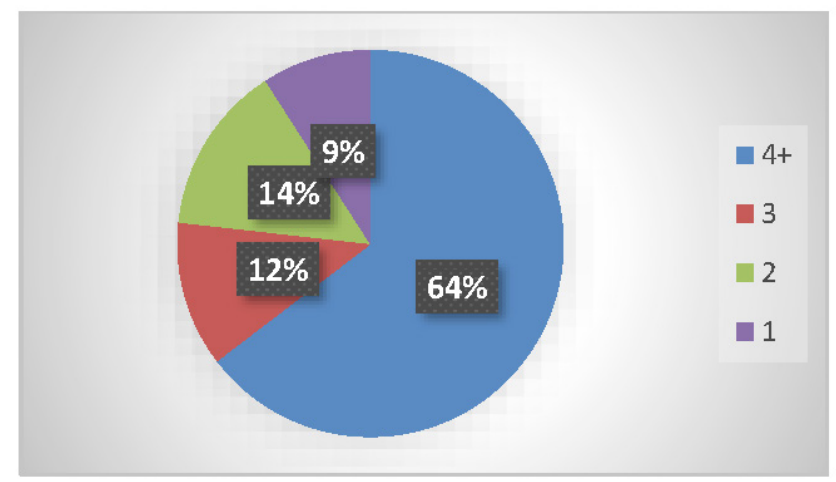

Figure 6. Results of Respondent's Answers on the Dimension of Notion Source: Researcher Data

The notion dimension describes the opinions held by content creators in conveying information about economics in Islamic religious education. In this dimension, the opinions conveyed by content creators must be in harmony with the material presented.

Based on Figure 6, it can be seen that $64 \%$ of respondents answered strongly agree that the notion of a content creator is needed to create good and reliable content. In this case, the dimension of notion can be in the form of opinions conveyed by content creators based on their knowledge of economics in Islamic religious education. The opinion must be based on facts and reliable sources so that there is no deviation of information. The results of this study are by the research conducted by Siti Rokiah Ab Rahman (2015), which explains that the credibility of YouTube as a medium for religious learning in contemporary Islamic civilization is very important in ensuring that the information disseminated meets the objective and is accepted as a trustworthy source because YouTube is viewed. as a medium that may appeal to Generation $\mathrm{Y}$ because it combines audio and visual elements in terms of being seen as more 
innovative and creative in the process of religious learning. This means that in creating content, further investigation is required or the information submitted must come from clear and reliable sources (Rahman \& Adam, 2015).

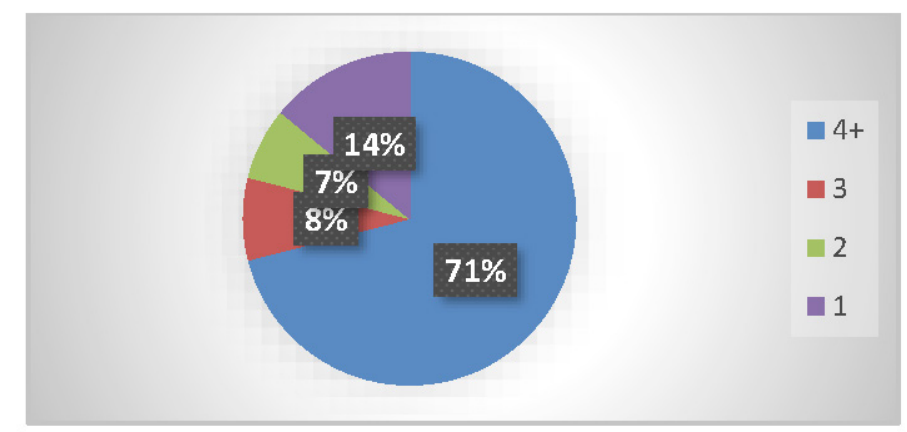

Figure 7. Results of Respondent's Answers on the Dimension of Human Resource

Source: Researcher Data

The human resource dimension describes the quantity and quality available in content regarding economics in Islamic religious education. In this dimension, quantity can be in the form of the number of content creators who are involved or who create content about economics in Islamic religious education. Meanwhile, quality can be in the form of the content creator's ability to present or convey the material/information.

Based on Figure 7, it can be seen that $71 \%$ of respondents answered strongly agree that resources are an important factor in creating quality content. In this case, the dimension of human resources has a quantity which is usually the number of people involved in content creation or content creators who create content about economics in Islamic religious education. Meanwhile, in this dimension, there is also the quality of human resources which is usually the ability or skill possessed by content creators in creating or delivering material about economics in Islamic religious education. The results of this study are related to research conducted by Renda Lestari (2013), which explains that YouTube is a learning medium that can be integrated into learning subjects that are considered difficult by students, one of which is learning English. This means that content creators must create quality and useful content for the audience as well as learning media that can make it easier for the community (Lestari, 2013). 
Descriptive data show that the dimensions of creativity, innovation, talent, ideas, ideas, resources have a positive value in each statement responded to by the respondent.

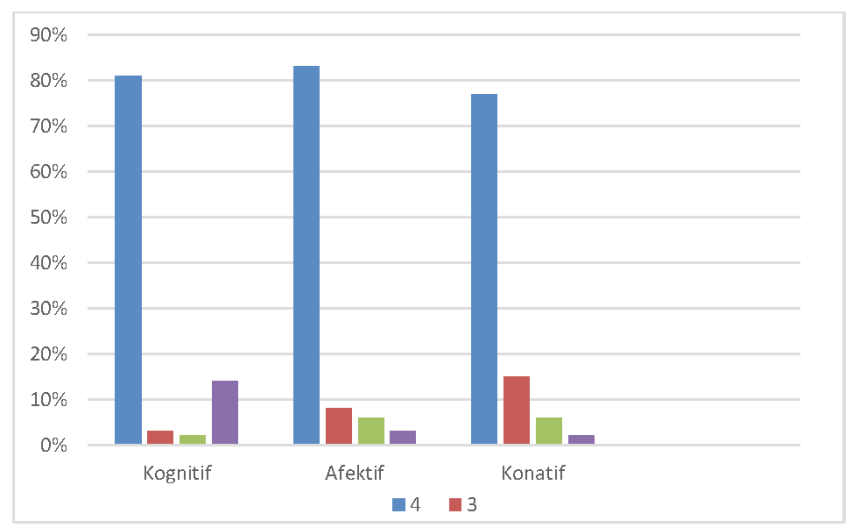

Figure 8. Descriptive Research Results

\section{Source: Researcher Data}

Figure 8 shows in the descriptive research results, there are 3 aspects reviewed, namely cognitive, affective, and conative. Cognitive data from respondents showed quite significant data by getting $81 \%$ results that respondents strongly agreed if they were already very good cognitively, while $3 \%$ of respondents answered agreed, $1 \%$ disagreed, and $15 \%$ answered strongly disagree.

Besides, the effective data shows that $82 \%$ answered strongly if they were very good affectively, while $8 \%$ of respondents answered agreed, $8 \%$ answered disagree, and $2 \%$ answered strongly disagreed. Likewise, $79 \%$ of respondents had answered strongly that they had maximally been conative, $15 \%$ answered agreed, $5 \%$ answered disagree, and $1 \%$ answered strongly disagree.

Descriptive data shows cognitive, affective, and conative values are positive in every statement responded to by the respondent. 


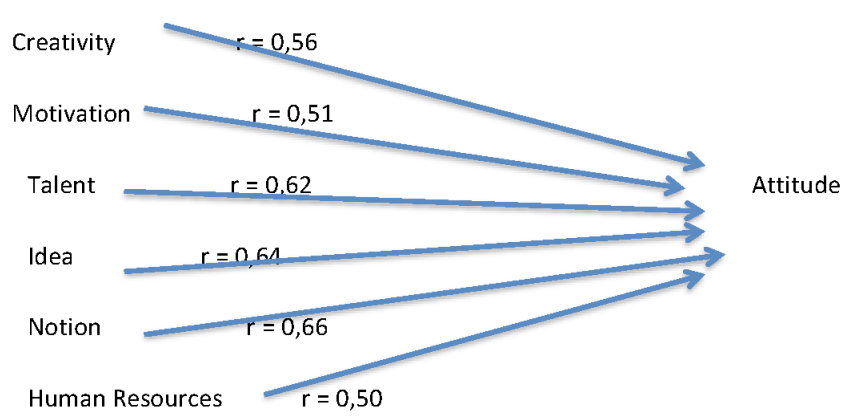

Figure 9. Linear Regression Test Results

Source: Researcher Data

All dimensions in this study have a strong influence on the attitude of YouTube users in creative economy information from an Islamic perspective. $\mathrm{Ha}$, all dimensions in the creative economy. The focus of this research is on how to commodify an economic perspective in the study of Islamic religious education on YouTube. The results of descriptive and regression conducted by researchers are of good value. However, the content of creative economy information in Islamic studies is not reflected explicitly. From several angles and messages conveyed by youtube, portals have been presented well.

Critical research in an objective matter has many perceptions that state studies that make people aware of certain things. Is there an ideology to be conveyed in the YouTube content in this study? The ideology that wants to be presented in this study is that society is doing a creative economy should ethics of doing business use transparent ethics to both parties. Then the community is invited to be able to appreciate the results of the creative ideas of a person or group.

\section{CONCLUSION}

Islamic religious education studies on social media YouTube are very important and beneficial for Muslims to learn and develop their economic commodification. Descriptive data in this study regarding the influence of the creative economy on the attitudes of YouTube media users. The creative economy has dimensions of creativity, innovation, talent, ideas, ideas, and human resources. The results of all these dimensions are positive in the responses of research respondents. In terms of the attitude of new media users, 
it is also positive. The researcher also conducted a regression test with the results that all ha were accepted and the research hypothesis was declared good.

\section{ACKNOWLEDGEMENT}

The researcher would like to thank Dean of Faculty of Administrative Sciences Universitas Indonesia, Dean of Faculty of Social Sciences Universitas Negeri Jakarta, and Dean of Faculty of Psychology Universitas Negeri Jakarta for the supports during the research.

\section{REFERENCES}

Amarasekara, I., \& Grant, W. J. (2019). Exploring the YouTube science communication gender gap: A sentiment analysis. Public Understanding of Science, 28(1), 68-84. https://doi.org/10.1177/0963662518786654

Ashidiqi, M. N. A., Rohmatiah, A., \& Rahmah, F. A. (2019). YouTube free Quran education as a source of Islamic education learning materials and media. Khalifa: Journal of Islamic Education, 3(2), 126-141. Retrieved from http://kjie.ppj.unp.ac.id/index.php/kjie/article/view/27

Baihaqi, A., Mufarroha, A., \& Imani, A. I. T. (2020). Youtube sebagai media pembelajaran Pendidikan Agama Islam efektif di SMK Nurul Yaqin Sampang. EDUSIANA: Jurnal Manajemen Dan Pendidikan Islam, 7(1), 74 88. Retrieved from http://journal.stainim.ac.id/index.php/edusiana/ article/view/19

David, E. R., Sondakh, M., \& Harilama, S. (2017). Pengaruh konten vlog dalam YouTube terhadap pembentukan sikap mahasiswa ilmu komunikasi Fakultas Ilmu Sosial dan Politik Universitas Sam Ratulangi. Acta Diurna Komunikasi, 6(1). Retrieved from https://ejournal.unsrat.ac.id/index. php/actadiurnakomunikasi/article/view/15479

Eddy, Usman, A., \& Dafitri, H. (2019). Peluang industri kreatif melalui pelatihan pembuatan video kreatif bagi mahasiswa Akademi Dakwah Indonesia Sumatera Utara. Jtunas, 1(1), 39. https://doi.org/10.30645/ jtunas.v1i1.11

Faiqah, F., Nadjib, M., \& Amir, A. S. (2015). YouTube sebagai sarana komunikasi bagi komunitas Makassar vidgram. Jurnal Komunikasi KAREBA, 16(1), 28-42. https://doi.org/10.1080/14639947.2015.1006801 
Garrett, N. (2016). Mapping self-guided learners' searches for video tutorials on YouTube. Journal of Educational Technology Systems, 44(3), 319-331. https://doi.org/10.1177/0047239515615851

Irwandani, I., Iqbal, M., \& Latifah, S. (2019). Pengembangan video blog (Vlog) channel YouTube dengan pendekatan stem sebagai media alternatif pembelajaran daring. Inovasi Pembangunan : Jurnal Kelitbangan, 7(2), 135. https://doi.org/10.35450/jip.v7i2.140

Kamhar, M. Y., \& Lestari, E. (2019). Pemanfaat sosial media YouTube sebagai media pembelajaran Bahasa Indonesia di perguruan tinggi. INTELIGENSI: Jurnal Ilmu Pendidikan, 1(2), 1-7. https://doi.org/10.33366/ilg.v1i2.1356

Lestari, R. (2013). Penggunaan YouTube sebagai media pembelajaran Bahasa Inggris. Seminar Nasional Kedua Pendidikan Berkemajuan Dan Menggembirakan (The Second Progressive and Fun Education Seminar), 607-612. Retrieved from https://publikasiilmiah.ums.ac.id/handle/11617/9566

Madathil, K. C., Rivera-Rodriguez, A. J., Greenstein, J. S., \& Gramopadhye, A. K. (2015). Healthcare information on YouTube: A systematic review. Health Informatics Journal, 21(3), 173-194. https://doi. org/10.1177/1460458213512220

Mosemghvdlishvili, L., \& Jansz, J. (2013). Framing and praising Allah on YouTube: Exploring user-created videos about Islam and the motivations for producing them. New Media and Society, 15(4), 482-500. https://doi. org/10.1177/1461444812457326

Neuman, W. L. (2014). Social research methods: Qualitative and quantitative approaches (7th ed.). Pearson Education Limited.

Payne, N. J., Campbell, C., Bal, A. S., \& Piercy, N. (2011). Placing a hand in the fire: Assessing the impact of a YouTube experiential learning project on viral marketing knowledge acquisition. Journal of Marketing Education, 33(2), 204-216. https://doi.org/10.1177/0273475311410853

Pratiwi, B., \& Puspito Hapsari, K. (2020). Analisis kemampuan berpikir tingkat tinggi melalui pemanfaatan YouTube sebagai media pembelajaran Bahasa Indonesia. Jurnal Ilmiah Sekolah Dasar, 4(2), 282. https://doi. org/10.23887/jisd.v4i2.24238

Quennerstedt, M., Flintoff, A., \& Webb, L. (2013). Narratives from YouTube: Juxtaposing stories about physical education. SAGE Open, 3(4). https:// doi.org/10.1177/2158244013507266 
Rahman, S. R. A., \& Adam, F. (2015). Kredibiliti YouTube sebagai medium pembelajaran agama dalam peradaban Islam kontemporari. Proceedings of ICIC2015 - International Conference on Empowering Islamic Civilization in the 21st Century, September, 593-599.

Rahmawan, D., Mahameruaji, J. N., \& Janitra, P. A. (2018). Potensi YouTube sebagai media edukasi bagi anak muda. Edulib: Journal of Library and Information Science, 8(1), 81-98. https://doi.org/10.17509/edulib. v8i1.11267

Sari, L. (2020). Upaya menaikkan kualitas pendidikan dengan pemanfaatan YouTube sebagai media ajar pada masa pandemi Covid-19. Jurnal Tawadhu, 4(1), 1074-1084. Retrieved from https://ejournal.iaiig.ac.id/ index.php/TWD/article/view/226

Smith, R., \& Secoy, J. (2019). Exploring the music identity development of elementary education majors using ukulele and YouTube. Journal of Music Teacher Education, 29(1), 71-85. https://doi. org/10.1177/1057083719871026

Suwarno, M. (2017). Potensi YouTube sebagai sumber belajar Matematika. Pi: Mathematics Education Journal, 1(1), 1-7. https://doi.org/10.21067/pmej. v1i1.1989

Ulya, H. (2019). Komudifikasi pekerja pada YouTube pemula dan underrated (Studi kasus YouTube Indonesia). Interaksi: Jurnal Ilmu Komunikasi, 8(2), 1. https://doi.org/10.14710/interaksi.8.2.1-12

Utaminingrum, K. A. (2015). YouTube sebagai media pembelajaran budaya Korea Selatan (Studi kasus pada anggota komunitas Cover Dance Soulmate Community) (Doctoral dissertation, Bakrie University). Retrieved from https://www.neliti.com/publications/253939/youtube-sebagai-mediapembelajaran-budaya-korea-selatan-studi-kasus-pada-anggota

Welbourne, D. J., \& Grant, W. J. (2016). Science communication on YouTube: Factors that affect channel and video popularity. Public Understanding of Science, 25(6), 706-718. https://doi.org/10.1177/0963662515572068 